\title{
An Effect of Different Parameters of Fins on Heat Transfer of IC Engine- Review Study
}

\author{
Prof. Arvind S. Sorathiya ${ }^{1}$, Hiren P. Hirpara ${ }^{2}$, Prof. Dr. P.P. Rathod ${ }^{3}$ \\ ${ }^{I}$ (Mechanical Engineering Department, Government Engineering College-Bhuj, India) \\ ${ }^{2}$ (Mechanical Engineering Department, Government Engineering College-Bhuj, India) \\ ${ }^{3}$ (Mechanical Engineering Department, Government Engineering College-Bhuj, India)
}

\begin{abstract}
To Study Of Different Research Papers Related To The Extended Surfaces And Effect On Heat Transfer Rate By Changing The Cross-Section, Fin Pitch, Fin Material, Fin Thickness, Air Velocity, And Air Exposed Angle Etc. And Survey Has Been Conducted On Fin Profile Of Various Cylinder Block Of Two/Three Wheelers Automobiles Available In India. The Fins Are Generally Used To Increase The Heat Transfer Rate By Increasing The Area Of System. So It Is Necessary To Study About Effect Of Fin Geometry On Heat Transfer Rate. This Review Study Is Useful To Know Betterment Of Fin Material And Fin Geometry.
\end{abstract}

\section{Introduction}

In case of Internal Combustion engines, combustion of air and fuel takes place inside the engine cylinder and hot gases are generated. The temperature of gases will be around $2300-2500^{\circ} \mathrm{C}$. This is a very high temperature and may result into burning of oil film between the moving parts and may result into seizing or welding of the same. So, this temperature must be reduced to about $150-200^{\circ} \mathrm{C}$ at which the engine will work most efficiently. Too much cooling is also not desirable since it reduces the thermal efficiency. So, the object of cooling system is to keep the engine running at its most efficient operating temperature. It is to be noted that the engine is quite inefficient when it is cold and hence the cooling system is designed in such a way that it prevents cooling when the engine is warming up and till it attains to maximum efficient operating temperature, then it starts cooling. It is also to be noted that:

(a) $20-25 \%$ of total heat generated is used for producing brake power (useful work).

(b) Cooling system is designed to remove $30-35 \%$ of total heat.

(c) Remaining heat is carried away by exhaust gases. The aim of this review is to find out the effect of fin geometry and fin pitch on cooling of the engine.

\section{Literature Review}

Bassam A/K Abu-Hijleh ${ }^{[1]}, \mathbf{2 0 0 3}$, numerically investigated problem of cross flow forced convection heat transfer from a horizontal cylinder with multiple, equally spaced, high conductivity permeable fins on its outer surface. The heat transfer characteristics of cylinder with permeable and solid fins were studied with different parameters like number of fins, and fins heights with wide range of Reynolds number (5-200). From this study it has been observed that permeable fins offered much higher Nusselt number than the solid fins under the same operating condition. Permeable fins resulted in much larger aerodynamic and thermals wakes which significantly reduced the effectiveness of the downstream fins, especially at $\Theta<90^{\circ}$. A single long permeable fin tended to offer the best convection heat transfer from a cylinder. This has great practical implications in terms of weight and cost of fins needed to achieve a certain level of heat transfer enhancement.

Masao YOSHIDA et al ${ }^{[2]}, \mathbf{2 0 0 6}$, experimentally investigated the effect of number of fins, fin pitch and wind velocity on air cooled engine of motorcycle. Experimental cylinder that had a various number of circular fins and fin pitches were tested in wind tunnel. Then the temperature inside the cylinder, on the surface of the fins and in the space between the fins was measured. It was observed that the heat release from the cylinder did not improve when the cylinder have more fins and too narrow a fin pitch at lower wind velocities, because it is difficult for the air flow into the narrower space between fins, so temperature between them increased. The expression of average fin surface heat transfer coefficient derived from the fin pitch and wind velocity ( 0 to $60 \mathrm{KM} / \mathrm{hr}$ ).

$$
\alpha_{a v g}=\left(2.47-\frac{2.55}{p^{0.4}}\right) u^{0.9} 0.0827 p+4.31
$$


Table 2.1 Experimental cylinders, fins and air velocities Investigated by researchers

\begin{tabular}{|c|c|c|c|c|c|}
\hline Parameters & $\begin{array}{c}\text { Gibson } \\
\text { A.H. }\end{array}$ & $\begin{array}{c}\text { Bierman } \\
\text { n A.E.et } \\
\text { al. }\end{array}$ & \multicolumn{2}{|c|}{$\begin{array}{c}\text { Thronhill D. et } \\
\text { al. }\end{array}$} & $\begin{array}{c}\text { Masao } \\
\text { Yoshida } \\
\text { M. et al. }\end{array}$ \\
\hline $\begin{array}{c}\text { Cylinder } \\
\text { diameter (mm) }\end{array}$ & $32-95$ & 118.36 & 86 & 100 & 78 \\
\hline Fin pitch (mm) & $4-19$ & $\begin{array}{c}1.448- \\
15.24\end{array}$ & $7-14$ & $8-14$ & $7-20$ \\
\hline $\begin{array}{c}\text { Fin Length } \\
\text { (mm) }\end{array}$ & $16-41$ & $\begin{array}{c}9.398- \\
37.33\end{array}$ & $25-65$ & $\begin{array}{c}10- \\
50\end{array}$ & 35 \\
\hline $\begin{array}{c}\text { Material } \\
\text { Copper, }\end{array}$ & Steel, Al & Steel & Al alloy & Al \\
\hline $\begin{array}{c}\text { Wind Velocity } \\
\text { (Km/hr) }\end{array}$ & $32-97$ & $\begin{array}{c}46.8- \\
241.2\end{array}$ & $\begin{array}{c}43.2- \\
172.8\end{array}$ & $\begin{array}{c}7.2- \\
72\end{array}$ & $0-60$ \\
\hline
\end{tabular}

They have concluded that the optimized fin pitches with the greatest effective cooling are at $20 \mathrm{~mm}$ for nonmoving and $8 \mathrm{~mm}$ for moving.

Fernando Illán et al ${ }^{[3]}, \mathbf{2 0 1 0}$, in this paper heat transfer from cylinder to air of two stroke internal combustion finned engine has been simulated. For this purpose, a 2D model has been done. Starting from the geometry of a real engine, annular cylindrical and spherical symmetric walls to fins has been used to obtain an equivalent simplified geometry, where the heat transfer rate is the same as that in the real engine. The cylinder body, cylinder head (both provided with fins), and piston have been numerically analyzed and optimized in order to minimize engine dimensions. The maximum temperature admissible at the hottest point of the engine has been adopted as the limiting condition. Following are the engine parameters which has been used in study:

\section{Table 2.2 Engine Parameters}

\begin{tabular}{|l|l|}
\hline Engine Speed (RPM) & 6000 \\
\hline Bore B (mm) & 43 \\
\hline Stroke L (mm) & 33.74 \\
\hline Clearance Volume $\left(\mathrm{mm}^{3}\right)$ & 6000 \\
\hline Compression Ratio & 9.167 \\
\hline Connection rod length (mm) & 62.48 \\
\hline $\begin{array}{l}\text { Ratio of connecting rod length to crank } \\
\text { radius }\end{array}$ & 3.704 \\
\hline
\end{tabular}

From the simulation they have concluded that a total reduction of $20.15 \%$ has been achieved by reducing the total engine diameter $\mathrm{D}$ from $90.62 \mathrm{~mm}$ to $75.22 \mathrm{~mm}$ and by increasing the total height $\mathrm{H}$ from $125.72 \mathrm{~mm}$ to $146.47 \mathrm{~mm}$ aspect ratio varies from 1.39 to 1.95 . In parallel with the total volume reduction, a slight increase in engine efficiency has been achieved.

Ashok tukaram pise et al ${ }^{[4]}, \mathbf{2 0 1 0}$, in this paper natural convection heat transfer from solid and permeable fins are investigated by experimental analysis. Permeable fins are formed by modifying the solid rectangular fins with drilling three holes per fins inline at one half lengths of the fins of two wheeler cylinder block. Engine cylinder blocks having solid and permeable fins were tested for different inputs like $75 \mathrm{~W}, 60 \mathrm{~W}, 45 \mathrm{~W}, 30 \mathrm{~W}$ and $15 \mathrm{~W}$.

They had derived following observations from their experimental works:

Temperature profile shows that the base temperatures of solid fins are more elevated as compared to permeable fins. Also the tip temperatures of solid fins are more elevated as compared to permeable fins. It means that heat transfer rate is more in permeable fins as compared to the solid fins.

- $\quad$ The average heat transfer coefficient and the ratio of heat transfer coefficient of the cylinder with permeable fins to the cylinder with solid fins have been increased by significance value.

- There is reduction in area due to which material cost are less about 10-30\%.

S. H. Barhatte et al ${ }^{[5]}$, 2011, in this paper natural convection heat transfer from vertical rectangular fin arrays with and without notch at the center have been investigated experimentally and theoretically. It was observed that heat transfer coefficient and in turn the rate of heat transfer can further be increased by increasing the surrounding fluid velocity i.e. by forced convection. It is also observed that heat transfer coefficient is highest for the set of fins with triangular notch. Results has been shown by the CFD as well as experimental analysis in table 2.3 . 
Table 2.3 Comparison of heat transfer coefficient (HTC) by CFD and HTC by experiment

\begin{tabular}{|c|c|c|c|}
\hline Properties & Copper & Aluminum & Unit \\
\hline Density & 8933 & 2700 & $\mathrm{Kg} / \mathrm{m}^{3}$ \\
\hline $\begin{array}{c}\text { Coefficient of } \\
\text { expansion }\end{array}$ & 10 & 10 & $1 / \mathrm{K}$ \\
\hline $\begin{array}{c}\text { Thermal } \\
\text { Conductivity }\end{array}$ & 398 & 236 & $\mathrm{~W} / \mathrm{m}^{2} \mathrm{~K}$ \\
\hline Specific heat & 385 & 900 & $\mathrm{~J} / \mathrm{Kg} \mathrm{K}$ \\
\hline
\end{tabular}

Table 2.4 Properties of Copper and Aluminum

\begin{tabular}{|c|c|c|c|c|c|}
\hline \multirow{2}{*}{$\begin{array}{c}\text { Base } \\
\text { Temp. of } \\
60^{\circ} \mathrm{C}\end{array}$} & \multicolumn{5}{|c|}{ Average Heat Transfer Coefficient $\left(\mathrm{W} / \mathrm{m}^{2} \mathrm{~K}\right)$} \\
\cline { 2 - 6 } & $\begin{array}{c}\text { W/o. } \\
\text { Notches }\end{array}$ & Rectangular & Circular & Triangular & $\begin{array}{c}\text { Trape } \\
\text { zoida } \\
1\end{array}$ \\
\hline CFD & 5.3434 & 6.039 & 5.31779 & 7.03509 & $\begin{array}{c}7.026 \\
0\end{array}$ \\
\hline $\begin{array}{c}\text { Experime } \\
\text { ntal }\end{array}$ & 6.231 & 6.07 & 6.18882 & 6.29172 & $\begin{array}{c}6.100 \\
4\end{array}$ \\
\hline
\end{tabular}

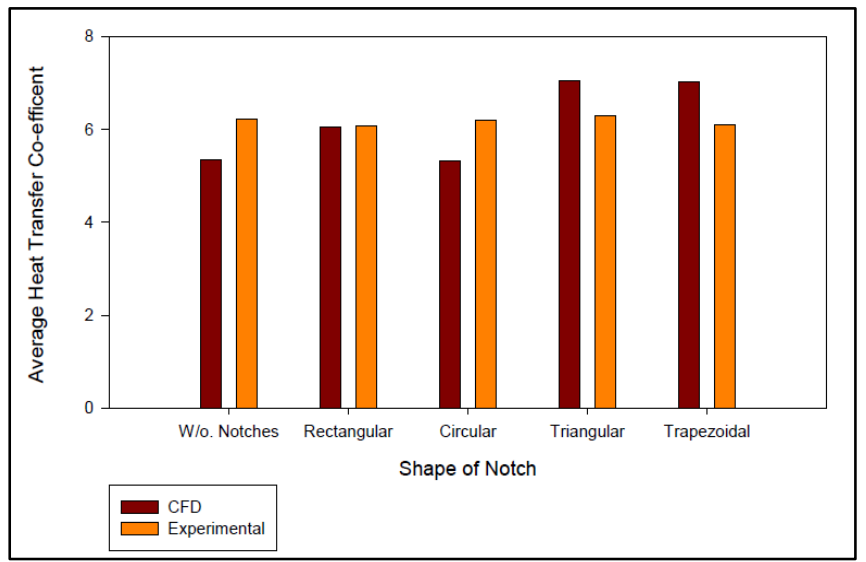

Fig. 2.1 Comparison of heat transfer coefficient (HTC) by CFD and HTC by experiment [5]

Pulkit Agarwal et al ${ }^{[6]}, 2011$, in this paper heat transfer rate depends upon the velocity of the vehicle, fin geometry and ambient temperature. An attempt was made to simulate the heat transfer using CFD analysis. The heat transfer surface modelled in GAMBIT and simulated in FLUENT software. An expression of average fin surface heat transfer coefficient in terms of wind velocity is obtained. A mathematical relation of the average surface heat transfer coefficient in terms of wind velocity was formulated by using the empirical relation:

$h=5.108 u^{0.643}$

The values of heat flux through the fin surface and wind velocity were used to solve the empirical equation.

Table 2.5 Heat Flux at different velocities

\begin{tabular}{|l|l|l|l|}
\hline Velocity (km/hr) & 40 & 60 & 72 \\
\hline Heat flux (W) & 724 & 933.56 & 1123.03 \\
\hline
\end{tabular}

It is observed that when the ambient temperature reduces to a very low value, it results in overcooling and poor efficiency of the engine. They have concluded that overcooling also affects the engine efficiency because of overcooling excess fuel consumption occurs. This necessitates the need for reducing air velocity striking the engine surface to reduce the fuel consumption. It can be done placing a diffuser in front of the engine which will reduce the relative velocity of the air stream thus decreasing the heat loss.

Magarajan $U$ et al ${ }^{[7]}, \mathbf{2 0 1 2}$, in this paper heat release from an IC engine cylinder cooling fins with six number of fins having pitch of $10 \mathrm{~mm}$ and $20 \mathrm{~mm}$ are calculated numerically using commercially available CFD tool 
ANSYS Fluent. The IC engine is initially at $150{ }^{\circ} \mathrm{C}$ and the heat release form the cylinder is analyzed at a wind velocity of $0 \mathrm{KM} / \mathrm{hr}$. It is observed that CFD work and experimental work are approximately same. From CFD as well as experimental results it is possible to modify the fin geometry and predict the results. Changes like tapered fins, providing slits and holes in fin geometry.

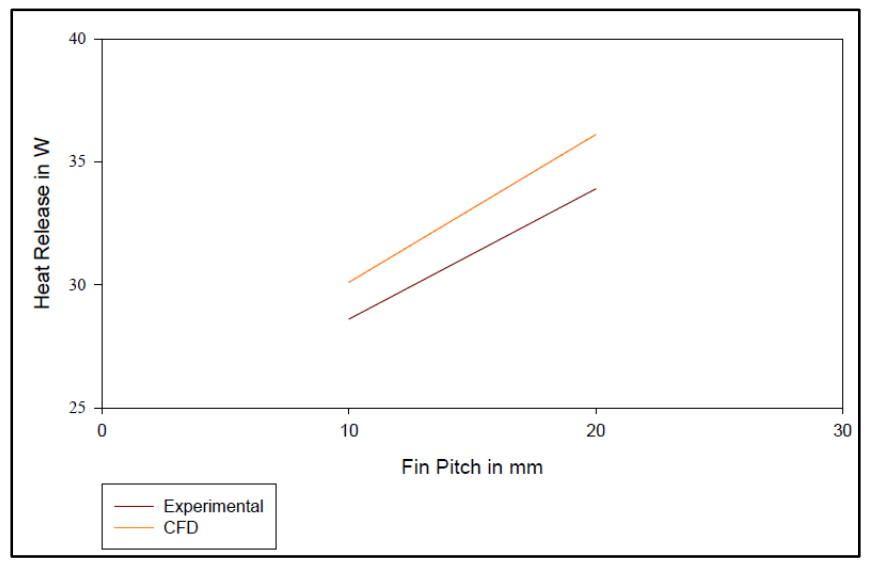

Fig 2.2 Comparison between CFD and experimental results [7]

Mishra A.K. et al ${ }^{[8]}, \mathbf{2 0 1 2}$, in this paper numerical investigation has been carried for a finned metal cylinder using CFD and is validated against the experiments carried out. A transient numerical analysis is carried out with wall cylinder wall temperature $423 \mathrm{~K}$ initially and heat release from the cylinder is analyzed for zero wind velocity. In this paper effort was made to study the effect of fin parameters on array performance which includes variation in pitch and fin material addition with consideration effect of wind velocity on cylinder pitch. It was observed that increase in cylinder cooling; cylinder should have a greater number of fins. However, the cylinder cooling may decrease with an increase number of fins and too narrow fin pitch. This study also reveals that the optimized fin material with the greatest effective cooling is copper, the effective heat transfer coefficient is found to be more for a pitch of $10 \mathrm{~mm}$.

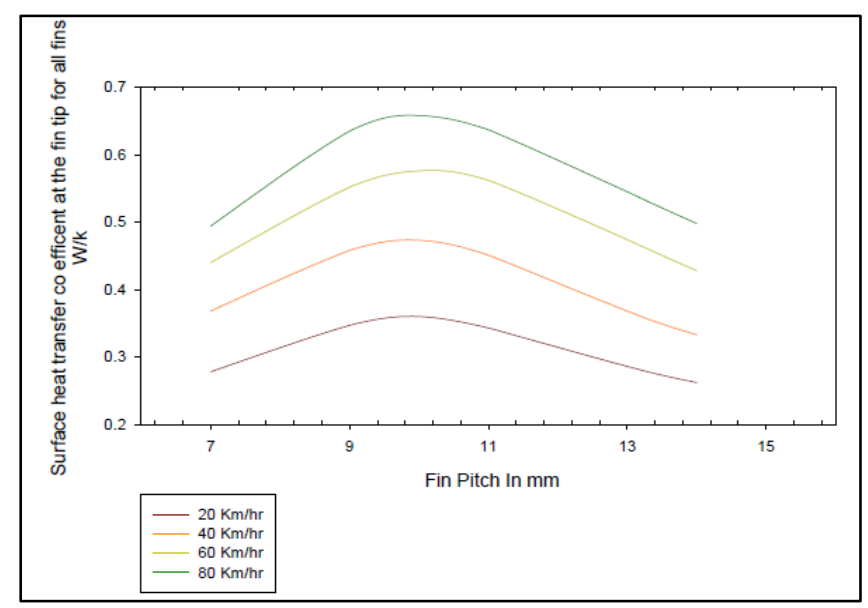

Fig.2.3 Heat dissipated by fins from tip at different velocities [8]

J.Ajay Paul et al ${ }^{[9]}, \mathbf{2 0 1 2}$, in this paper heat release characteristics of different fin parameters namely, number of fins, fin thickness, at varying air velocities for a single cylinder air cooled engine by numerically using CFD and experimentally by wind tunnel. Cylinder with fins of $4 \mathrm{~mm}$ and $6 \mathrm{~mm}$ thickness were simulated for 1, 3, 4, \& 6 fin configuration. Cylinder material was cast iron and fin material was aluminum alloy 6101 .

They had derived following observations from their experimental works:

- The difference of heat transfer from $4 \mathrm{~mm}$ and $6 \mathrm{~mm}$ fins are negligibly same at zero velocity.

- Heat transfer increased with increase the fin thickness.

- Large number of fins with less thickness can be preferred in high speed vehicles than thick fins with less number as it helps inducing greater turbulence and hence higher heat transfer.

- The heat transfers from the outside portion of the fins are less, so we can improve that by changing the 
geometry of fins.

G. Raju et al ${ }^{[10]}, \mathbf{2 0 1 2}$, in this paper maximization of heat transfer thorough fins arrays of an internal combustion engine cylinder have been investigated, under one dimensional, steady state conduction and free convection modes. In this study binary coded generic algorithm technique is used to obtain maximum heat transfer and corresponding optimum dimensions of rectangular and triangular profile fin array. This study also includes the effect of spacing between fins on various parameters like total surface area, heat transfer coefficient and total heat transfer.

They had derived following observations from experimental works:

- Heat transfer through triangular fin array per unit mass is more than that of heat transfer through rectangular fin array. Therefore the triangular fins are preferred than the rectangular fins for automobiles, central processing units, aero-planes, space vehicles etc. where, weight is the main criteria.

- At wider spacing, shorter fins are more preferred than longer fins.

- The aspect ratio for an optimized fin array is more than that of a single fin for both rectangular and triangular profiles.

Rajeev P Patil et al ${ }^{[11]}, \mathbf{2 0 1 3}$, in this paper effect of forced convection on heat transfer parameter, heat transfer coefficient and tube efficiency of elliptical fins has been analyzed by CFD and experimental analysis. The heat transfer parameter analyzed at different operating condition. The experiment was carried out at different air flow rate.

They had derived following observations from experimental works:

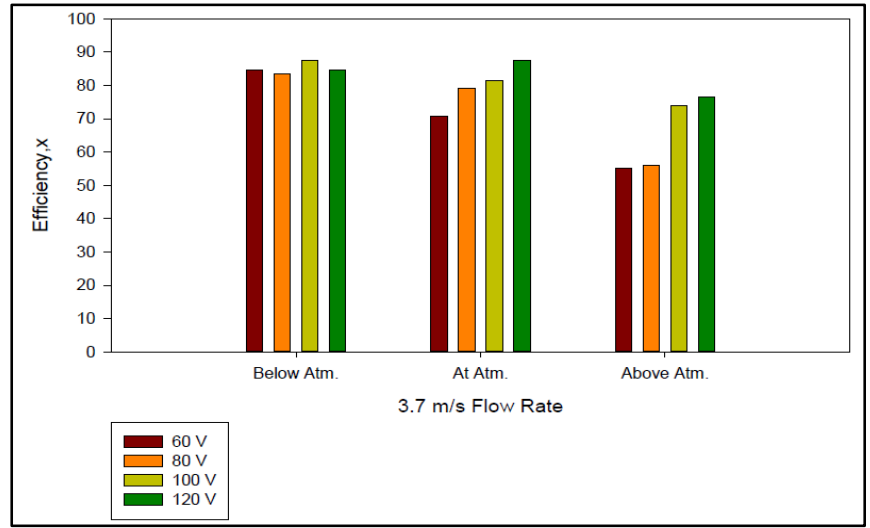

Fig 2.4 Graph of efficiency at different environmental conditions for $3.7 \mathrm{~m} / \mathrm{s}$ flow rate [11]

- For $3.7 \mathrm{~m} / \mathrm{s}$ flow rate at atm. temperature and $\mathrm{V}=60, \mathrm{~V}=80, \mathrm{~V}=100$ and $\mathrm{V}=120, \mathrm{CFD}$ results shows that the temperature is gradually decreasing on major axis of elliptical fin.

- At air flow rate of $3.7 \mathrm{~m} / \mathrm{s}$ the efficiency increases as heat input increases. The efficiency increases as heat input increases. Also efficiency is higher at below atmospheric temperature and lower at above atmosphere temperature.

- Experimental results show that the temperatures at middle of fin indicate slight increase in temp. That is because of combined effect of convection and conduction.

G babu et al ${ }^{[12],}$ 2013, in this paper thermal properties by varying geometry, material and thickness of cylinder fins by CFD analysis. The models of different geometry like rectangular, circular, and curved shape fins using ProE software. Material used for manufacturing cylinder fin body is aluminum Alloy 204 which has thermal conductivity of $110-150 \mathrm{~W} / \mathrm{m} \mathrm{k}$. it has also analyze different material like aluminum 6061, Magnesium. They have concluded that aluminium alloy 6061 is better, reducing thickness to $2.5 \mathrm{~mm}$ is better and using fin shape circular by analysis and fin shape curved by weight is better.

K. shahril et al ${ }^{[13]}, \mathbf{2 0 1 3}$, in this paper heat transfer rate depending on velocity of vehicle, fin geometry and the ambient temperature can be analysed by CFD analysis in ANSYS. For the CFD analysis they have chosen two engine cylinder block of different bikes like Yamaha Lagenda and Modenas Kriss 110. They have concluded that wind velocity is one important parameter that can be affects the total heat transfer and value of heat transfer coefficient.

Shinde sandip chandrakant et al ${ }^{[14]}, \mathbf{2 0 1 3}$, in this paper heat transfer rate from the rectangular and triangular profile at 0 to $11 \mathrm{~m} / \mathrm{s}$ velocity has been investigated by experimental as well as CFD analysis.

Following observations were made from their experimental/CFD works:

- The air flow velocity in abstraction with rectangular fin profile is higher than triangular fin profiles.

- Surface temperature of triangular fin profile is higher than rectangular fin profile at different air velocity. 
- Amount of heat transfer increases with decreasing the surface temperature or increasing air velocity in both profiles. In comparison of both profile rectangular fin profile transfer large amount of heat than triangular fin profile.

III. Survey on Indian Si Air Cooled Engine Cylinder Fins.

\begin{tabular}{|c|c|c|c|c|}
\hline \multicolumn{2}{|c|}{$\begin{array}{l}\text { Photograph } \\
\text { ic View of } \\
\text { Model }\end{array}$} & $\frac{1}{x-2}=$ & $: 8$ & \\
\hline \multicolumn{2}{|l|}{$\begin{array}{l}\text { Model } \\
\text { Name }\end{array}$} & $\begin{array}{l}\text { Hero Honda } \\
\text { Karizma }\end{array}$ & Yamaha Fazer & Honda Unicorn \\
\hline \multicolumn{2}{|l|}{$\mathrm{CC}$} & 225 & 153 & 149 \\
\hline \multicolumn{2}{|l|}{$\begin{array}{l}\begin{array}{l}\text { Stroke } \\
(\mathbf{m m})\end{array} \\
\end{array}$} & 66.2 & 57.9 & 58 \\
\hline \multicolumn{2}{|c|}{ Bore (mm) } & 65.5 & 58 & 57 \\
\hline \multicolumn{2}{|c|}{ No. of Fins } & 8 & 7 & 6 \\
\hline \multicolumn{2}{|c|}{$\begin{array}{l}\text { Fin } \\
\text { Pitch (mm) }\end{array}$} & 10 & 10 & 7 \\
\hline \multicolumn{2}{|c|}{$\begin{array}{l}\text { Fin } \\
\text { Thickness } \\
(\mathbf{m m}) \\
\end{array}$} & 2 & 3 & 3 \\
\hline \multicolumn{2}{|c|}{$\begin{array}{l}\text { Fin } \\
\text { Material }\end{array}$} & $\mathrm{Al}$ & Al alloy & Al Alloy \\
\hline \multicolumn{2}{|c|}{$\begin{array}{l}\text { Position of } \\
\text { fins w.r.t. } \\
\text { cylinder } \\
\text { axis } \\
\end{array}$} & Perpendicular & Perpendicular & Perpendicular \\
\hline \multicolumn{2}{|c|}{$\begin{array}{l}\text { Position of } \\
\text { cylinder in } \\
\text { vehicle }\end{array}$} & Incline & Incline & Incline \\
\hline \multirow{2}{*}{$\begin{array}{l}\text { Fin } \\
\text { Height } \\
(\mathrm{mm})\end{array}$} & \begin{tabular}{l|}
$\mathbf{M}$ \\
$\mathbf{a}$ \\
$\mathbf{x}$
\end{tabular} & 23 & 24 & 13 \\
\hline & $\begin{array}{l}\mathbf{M} \\
\mathbf{i} \\
\mathbf{n}\end{array}$ & 12 & 5 & 9 \\
\hline \multicolumn{2}{|l|}{$\begin{array}{l}\text { Courtesy } \\
\text { by }\end{array}$} & $\begin{array}{l}\text { Apex Honda, } \\
\text { Maninagar, } \\
\text { Ahmedabad, } \\
\text { Gujarat, India }\end{array}$ & $\begin{array}{l}\text { Yamaha } \\
\text { Service } \\
\text { Center, } \\
\text { Maninagar, } \\
\text { Ahmedabad, } \\
\text { Gujarat, India }\end{array}$ & $\begin{array}{l}\text { Apex Honda, } \\
\text { Maninagar, } \\
\text { Ahmedabad, } \\
\text { Gujarat, India }\end{array}$ \\
\hline
\end{tabular}

\begin{tabular}{|l|l|l|l|}
\hline $\begin{array}{l}\text { Photographic } \\
\text { View of } \\
\text { Model }\end{array}$ & Bajer| & \\
\hline Model Name & Bajaj Pulser & Bajaj 2s RE & Bajaj Pulser \\
\hline CC & 149 & 145.45 & 135 \\
\hline Stroke (mm) & 56 & 57 & 54 \\
\hline Bore (mm) & 57 & 57 & 59 \\
\hline No. of Fins & 6 & 10 & 6 \\
\hline $\begin{array}{l}\text { Fin } \\
\text { Pitch (mm) }\end{array}$ & 11 & 8 & 10 \\
\hline $\begin{array}{l}\text { Fin } \\
\text { Thickness } \\
\text { (mm) }\end{array}$ & 2 & 2.5 & 2 \\
\hline Fin Material & Al Alloy & Cast Iron & Al Alloy \\
\hline $\begin{array}{l}\text { Position of } \\
\text { fins w.r.t. } \\
\text { cylinder axis }\end{array}$ & Perpendicular & Perpendicular & Perpendicular \\
\hline
\end{tabular}




\begin{tabular}{|c|c|c|c|c|}
\hline \multicolumn{2}{|c|}{$\begin{array}{l}\text { Position of } \\
\text { cylinder in } \\
\text { vehicle }\end{array}$} & Incline & Horizontal & Incline \\
\hline \multirow{2}{*}{$\begin{array}{l}\text { Fin } \\
\text { Height } \\
(\mathbf{m m})\end{array}$} & $\begin{array}{l}\mathrm{m} \\
\mathrm{a} \\
\mathrm{x}\end{array}$ & 35 & 29 & 35 \\
\hline & $\begin{array}{l}\mathrm{m} \\
\mathrm{i} \\
\mathrm{n}\end{array}$ & 10 & 19.5 & 10 \\
\hline \multirow{2}{*}{\multicolumn{2}{|c|}{$\begin{array}{l}\text { Courtesy by } \\
\text { Photographic }\end{array}$}} & Bajaj Service. & & Bajaj Service, \\
\hline & & $\begin{array}{l}\text { Bapunagar, } \\
\text { Anmedabad, } \\
\text { Gujarat,India }\end{array}$ & H. S.Auto & $\begin{array}{l}\text { Bapunagar, } \\
\text { Ahnectabad, } \\
\text { Gujarat,logita }\end{array}$ \\
\hline \multicolumn{2}{|c|}{ Model Name } & Honda Shine & Bajaj Chetak & TVS Victor \\
\hline \multicolumn{2}{|c|}{$\mathrm{CC}$} & 125 & 124.6 & 109.3 \\
\hline \multicolumn{2}{|c|}{ Stroke $(\mathrm{mm})$} & 58 & 54.4 & 53.5 \\
\hline \multicolumn{2}{|c|}{ Bore (mm) } & 52 & 54 & 51 \\
\hline \multicolumn{2}{|c|}{ No. of Fins } & 6 & 6 & 7 \\
\hline \multicolumn{2}{|c|}{$\begin{array}{l}\text { Fin } \\
\text { Pitch }(\mathrm{mm})\end{array}$} & 10 & 9.5 & 9.5 \\
\hline \multicolumn{2}{|c|}{$\begin{array}{l}\text { Fin Thickness } \\
(\mathbf{m m})\end{array}$} & 2 & 3.5 & 2.5 \\
\hline \multicolumn{2}{|c|}{ Fin Material } & $\mathrm{Al}$ alloy & Al Alloy & Al Alloy \\
\hline \multicolumn{2}{|c|}{$\begin{array}{l}\text { Position of } \\
\text { fins w.r.t. } \\
\text { cylinder axis }\end{array}$} & Perpendicular & Perpendicular & Perpendicular \\
\hline \multicolumn{2}{|c|}{$\begin{array}{l}\text { Position of } \\
\text { cylinder in } \\
\text { vehicle }\end{array}$} & Incline & Horizontal & Incline \\
\hline \multirow{2}{*}{$\begin{array}{l}\text { Fin } \\
\text { Height } \\
(\mathrm{mm})\end{array}$} & $\begin{array}{l}\mathrm{M} \\
\mathrm{a} \\
\mathrm{x}\end{array}$ & 22 & 36 & 25 \\
\hline & $\begin{array}{l}\mathrm{M} \\
\mathrm{i} \\
\mathrm{n}\end{array}$ & 7 & 11 & 5 \\
\hline
\end{tabular}

\begin{tabular}{|l|l|l|l|}
\hline $\begin{array}{l}\text { Photographic } \\
\text { View of } \\
\text { Model }\end{array}$ & $\begin{array}{l}\text { Hero Honda } \\
\text { Passion }\end{array}$ & TVS Suzuki & Kinetic Honda \\
\hline Model Name & 109.1 & 100 & 100 \\
\hline CC & 55.6 & 50 & 50 \\
\hline Stroke (mm) & 50 & 50 & 50 \\
\hline Bore (mm) & $11-8-11$ & 11 & 7 \\
\hline No. of Fins & 9 & 3 & 10 \\
\hline $\begin{array}{l}\text { Fin } \\
\text { Pitch (mm) }\end{array}$ & 2 & Perpendicular & Perpendicular \\
\hline $\begin{array}{l}\text { Fin } \\
\text { Thickness } \\
\text { (mm) }\end{array}$ & 2 & Chilled Iron & Cast Iron \\
\hline Fin Material & Al Alloy & Parallel & $\begin{array}{l}\text { Position of } \\
\text { fins w.r.t. } \\
\text { cylinder axis }\end{array}$
\end{tabular}




\begin{tabular}{|c|c|c|c|c|}
\hline \multicolumn{2}{|c|}{$\begin{array}{l}\text { Position of } \\
\text { cylinder in } \\
\text { vehicle }\end{array}$} & Horizontal & Incline & Horizontal \\
\hline \multirow{2}{*}{$\begin{array}{l}\text { Fin } \\
\text { Height } \\
(\mathbf{m m})\end{array}$} & $\begin{array}{l}\mathbf{M} \\
\mathbf{a} \\
\mathbf{x}\end{array}$ & 36 & 47 & 33 \\
\hline & $\begin{array}{l}\mathbf{M} \\
\mathrm{i} \\
\mathrm{n}\end{array}$ & 8 & 30 & 9 \\
\hline \multicolumn{2}{|c|}{ Courtesy by } & $\begin{array}{l}\text { Rajdeep } \\
\text { Automobiles, } \\
\text { Ctm, } \\
\text { Ahmedabad, } \\
\text { Gujarat, India }\end{array}$ & $\begin{array}{l}\text { H.S. Auto } \\
\text { Rajkot }\end{array}$ & H.S. Auto Rajkot \\
\hline
\end{tabular}

\begin{tabular}{|c|c|c|c|c|}
\hline \multicolumn{2}{|c|}{$\begin{array}{l}\text { Photographic } \\
\text { View of } \\
\text { Model }\end{array}$} & & & \\
\hline \multicolumn{2}{|c|}{ Model Name } & $\begin{array}{l}\text { Hero Honda } \\
\text { CD delux }\end{array}$ & $\begin{array}{l}\text { Hero Honda } \\
\text { Splendor plus }\end{array}$ & Kinetic Luna \\
\hline \multicolumn{2}{|l|}{$\mathrm{CC}$} & 97.2 & 97.2 & 49.8 \\
\hline \multicolumn{2}{|c|}{ Stroke (mm) } & 49.5 & 49.5 & 43 \\
\hline \multicolumn{2}{|c|}{ Bore (mm) } & 50 & 50 & 38.4 \\
\hline \multicolumn{2}{|c|}{ No. of Fins } & $11-8-11$ & $11-8-11$ & 8 \\
\hline \multicolumn{2}{|c|}{$\begin{array}{l}\text { Fin } \\
\text { Pitch (mm) }\end{array}$} & 9 & 9 & 8 \\
\hline \multicolumn{2}{|c|}{$\begin{array}{l}\text { Fin Thickness } \\
\text { (mm) }\end{array}$} & 2 & 2 & 3 \\
\hline \multicolumn{2}{|c|}{ Fin Material } & Al Alloy & Al Alloy & Cast Iron \\
\hline \multicolumn{2}{|c|}{$\begin{array}{l}\text { Position of } \\
\text { fins w.r.t. } \\
\text { cylinder axis }\end{array}$} & Parallel & Parallel & Perpendicular \\
\hline \multicolumn{2}{|c|}{$\begin{array}{l}\text { Position of } \\
\text { cylinder in } \\
\text { vehicle }\end{array}$} & Horizontal & Horizontal & Horizontal \\
\hline \multirow{2}{*}{$\begin{array}{l}\text { Fin } \\
\text { Height } \\
(\mathrm{mm})\end{array}$} & $\begin{array}{l}\mathrm{M} \\
\mathrm{a} \\
\mathrm{x}\end{array}$ & 36 & 36 & 24 \\
\hline & $\begin{array}{l}\mathrm{M} \\
\mathrm{i} \\
\mathrm{n}\end{array}$ & 8 & 8 & 6 \\
\hline \multicolumn{2}{|c|}{ Courtesy by } & $\begin{array}{l}\text { H.S. Auto } \\
\text { Rajkot }\end{array}$ & $\begin{array}{l}\text { H.S. Auto } \\
\text { Rajkot }\end{array}$ & H.S. Auto Rajkot \\
\hline
\end{tabular}

\section{Summary/Conclusions}

The summary of the present review study are as follow:

1. Heat release from the cylinder did not improve when the cylinder had more fins and too narrow a fin pitch at lower wind velocities, because it is difficult for the air flow into the narrower space between fins, so temperature between them increased [2].

2. Optimized fin pitches with the greatest effective cooling are at $20 \mathrm{~mm}$ for non-moving and $8 \mathrm{~mm}$ for moving [2].

3. Heat transfer rate increase in permeable fins of same dimension solid fins.[4]

4. Material cost of fins are lesser $10-30 \%$ in permeable fins as compared to solid fins for same heat transfer rate.[4] 
5. Large number of fins with less thickness can be preferred in high speed vehicles than thick fins with less number as it helps inducing greater turbulence and hence higher heat transfer possible. [9]

6. Wider spacing shorter fins are prefer than the longer fins.[10]

7. Heat transfer rate and heat transfer coefficient can be increased with the wind velocity.[12]

8. Based on review study cylinder heat transfer rate also increase by changing the various types of geometry of fins mounted on it. That can be analyzed by CFD and validate results by conducting experimental work.

\section{References}

[1] Bassam A/K Abu-Hijleh, "Enhanced forced convection heat transfer from a cylinder using permeable fins", Journal of heat transfer, Vol. 125, 804-811, 2003

[2] Masao YOSHIDA et al, "Air-Cooling Effect of Fins on a Motorcycle Engine", JSME International journal, Series B, Vol.49, No. 3,869-875, 2006

[3] Fernando Illán et al, "Optimization of Annular Cylindrical and Spherical Fins in an Internal Combustion Engine under Realistic Conditions", Journal of Thermal Science and Engineering Applications, Vol. 2 / 041002-1-041002-7, 2010.

[4] Ashok tukaram pise et al, "Investigation of enhancement of natural convection heat transfer from engine cylinder with permeable fins", International Journal of Mechanical Engineering and Technology, Vol.1, No. 1, 238-247, 2010.

[5] S. H. Barhatte et al, "Experimental and Computational Analysis and Optimization for Heat Transfer through Fins with Different Types of Notch", Journal of Engineering Researches and Studies, Vol. II, 133-138, 2011.

[6] Pulkit Agarwal, et al, "Heat Transfer Simulation by CFD from Fins of an Air Cooled Motorcycle Engine under Varying Climatic Conditions", Proceedings of the World Congress on Engineering 2011 Vol. III WCE 2011, July 6 - 8, ISBN: 978-988-19251-5-2, 2011, London, U.K.

[7] Magarajan U et al., "Numerical Study on Heat Transfer of Internal Combustion Engine Cooling by Extended Fins Using CFD", Research Journal of recent sciences, Vol. 1(6), 32-37, 2012.

[8] Mishra A.K. et al, "Heat Transfer Augmentation of Air Cooled Internal Combustion Engine Using Fins through Numerical Techniques", Research journal of engineering sciences, Vol. 1(2), 32-40, 2012.

[9] J. Ajay Paul et al "Experimental and Parametric Study of Extended Fins in the Optimization of Internal Combustion Engine Cooling Using CFD", International Journal of Applied Research in Mechanical Engineering, ISSN: 2231-5590, Volume-2, Issue-1, 81-90, 2012 .

[10] G. Raju et al, "Optimal Design of an I.C. Engine Cylinder Fin Arrays Using a Binary Coded Genetic Algorithms", International Journal of Modern Engineering Research, Vol.2, Issue.6, pp-4516-4520, 2012.

[11] Rajeev P Patil et al, "Experimental and Computational Fluid Dynamics Heat Transfer Analysis on Elliptical Fin by Forced Convection”, International journal of engineering and research \& Technology, ISSN: 2278-0181, Vol. 2, Issue 8, 1582-1594, 2013.

[12] G babu et al, "Heat Transfer Analysis and Optimization of Engine Cylinder Fins of Varying Geometry and Material", IOSR Journal of Mechanical and Civil Engineering, Vol. 7, Issue 4, 24-29, 2013.

[13] K. shahril et al, "Heat transfer simulation of motorcycle fins under varying velocity using CFD method", 2nd International Conference on Mechanical Engineering Research (ICMER2013), doi:10.1088/1757-899X/50/1/012043,pp-1-6, 2013.

[14] Shinde sandip chandrakant et al, "Numerical and Experimental Analysis of Heat Transfer through Various Types of Fin Profiles by Forced Convection", International Journal of Engineering Research\& Technology, ISSN: 2278-0181, Vol. 2, Issue 7, 2493-2501, 2013. 